\title{
Effects of tributyltin (TBT) and testosterone on the female genital system in the mesogastropod Littorina littorea (Prosobranchia)
}

\author{
U. Deutsch \& P. Fioroni \\ Inst. für Spezielle Zoologie und Vergleichende Embryologie, University of Münster; \\ Hüfferstr. 1, D-48149 Münster, Germany
}

Manuscript received on 11th February 1994; accepted for publication on 29th June 1994

\begin{abstract}
Experiments were performed with the mesogastropod Littorina littorea on Helgoland, in Roscoff, and in the laboratory in order to evaluate the reaction of the female genital system to TBT, an environmental toxicant. The snails were either injected with 50 or $100 \mathrm{ng}$ tributyltin (TBT) soluted in ethanol or exposed to artificial sea water treated with 5,50,100, and $200 \mathrm{ng}$ TBT/l, and $33 \mathrm{ng}$ testosterone/l. The duration of the experiments was either four or eight weeks. None of the analysed female $L$. littorea showed signs of imposex. Compared to results for the control groups, the size of the female glandular complex was significantly reduced if the pre-experimental toxication was already high, as is the case in snails collected around Helgoland. TBT-related gland complex reduction occurs also in female $L$. littorea from other sampling sites. In addition, injection of ethanol also causes a decrease in gland size. The experimental results demonstrate that the distal female genital system responds with significantly lower sensitivity to TBT than that of other prosobranchs. This behaviour is ascribed to the lack of an androgen receptor at the ovipositor. The results further strengthen the case of the extreme rarity of imposex described for female $L$. littorea in natural habitats. However, strong TBT-toxication may affect $L$. littorea populations significantly because of increasing masculinization of the females, which reduces reproduction ability.
\end{abstract}

\section{INTRODUCTION}

The phenomenon of imposex (Smith, 1971) is defined as pathological variations in the distal genital system of marine prosobranchs. Imposex is induced by tributyltin (TBT), an organotin compound, which is used as a biocide in antifouling paints. According to Blaber (1970), Bryan et al. (1986), and Fioroni et al. (1991), the most drastic effects of TBTinduced imposex in female individuals of various prosobranchs are the following:

(a) the development of distal male genitals (vas deferens, penis) and

(b) oviduct-blockage, resulting in sterilization with lethal consequences.

So far, imposex has not been observed in the mesogastropod Littorina littorea (Matthiessen et al., 1991; Deutsch \& Brick, 1992). In principle, however, L. littorea is a most promising candidate for use as a tool in biomonitoring environmental toxicants because of its widespread occurrence in different habitats. The apparent lack of TBTinduced effects on the genital tract of female $L$. littorea was a reason to study systematically, through laboratory and field experiments, the reaction of L. littorea to TBT and testosterone. Experiments with testosterone were included in this study, because high 
testosterone levels in the environment have proved to promote masculinization in temale individuals of other prosobranchs (Stroben et al. 1991; Oehlmann et al. 1993a).

\section{MATERIAL AND METHODS}

Table 1 summarizes (1) the field experiments with injected snails in Roscoff (Brittany, France) and on Helgoland (German Bight) and (2) the laboratory experiments in basins filled with artificial seawater at the Zoological Institute in Münster:

(1) Wire-cages fixed in the tidal zone were used in both localities for the field experiments. 200 male and female $L$. littorea were randomly collected for each experiment. The specimens were narcotized for 20 minutes in $7 \% \mathrm{MgCl}_{2}$ and then injected with

Table 1. Total number of analysed female Littorina littorea

\begin{tabular}{|c|c|c|c|c|c|c|c|c|}
\hline \multirow{3}{*}{$\begin{array}{l}\text { Duration of exposure } \\
\text { (in weeks) }\end{array}$} & \multicolumn{2}{|c|}{ Field } & \multicolumn{6}{|c|}{ Laboratory } \\
\hline & 8 & 8 & 4 & 8 & 4 & 8 & 4 & 8 \\
\hline & $\begin{array}{l}\text { Adults } \\
\text { Helgoland }\end{array}$ & $\begin{array}{l}\text { Adults } \\
\text { Roscoff }\end{array}$ & \multicolumn{2}{|c|}{$\begin{array}{c}\text { Adults } \\
\text { Helgoland }\end{array}$} & \multicolumn{2}{|c|}{$\begin{array}{c}\text { Adults } \\
\text { Sion d'Ocean }\end{array}$} & \multicolumn{2}{|c|}{$\begin{array}{l}\text { Juveniles } \\
\text { Helgoland }\end{array}$} \\
\hline \multicolumn{9}{|l|}{ TBT injected } \\
\hline 50ng TBT & 4 & 15 & & 18 & & & & \\
\hline 100ng TBT & 0 & 14 & & 19 & & & & \\
\hline Control group & 13 & 13 & & 13 & & & & \\
\hline Solvent group & 12 & 15 & & 18 & & & & \\
\hline \multicolumn{9}{|l|}{ TBT aqueous exposure } \\
\hline 5ng TBT & & & & & 17 & 22 & & \\
\hline 50ng TBT & & & & & 16 & 17 & 10 & 10 \\
\hline 100ng TBT & & & & & 23 & 12 & & \\
\hline 200ng TBT & & & & & 11 & 15 & 13 & 14 \\
\hline \multicolumn{9}{|l|}{ Control group } \\
\hline \multicolumn{9}{|l|}{ Testosterone exposure } \\
\hline 33ng Testosterone & & & 12 & 10 & & & & \\
\hline Control group & & & 18 & 17 & & & & \\
\hline
\end{tabular}

50 or $100 \mathrm{ng}$ TBT (Sn soluted in 2 or $4 \mu \mathrm{l} 10 \%$ ethanol). The solutions add an additional body weight of 60.8 or $121.5 \mu \mathrm{g} \mathrm{TBT}$ (Sn/kg fresh weight) to L. littorea (average fresh weight of the soft body of $823 \mathrm{mg}$ ) used in experiments at Roscoff. At Helgoland, L. littorea shows a higher average fresh weight of the soft body of $1218 \mathrm{mg}$, and the additional body burden amounts to $41.1 \mu \mathrm{g}$ and $82.1 \mu \mathrm{g}$ TBT $(\mathrm{Sn} / \mathrm{kg})$. Totally untreated control groups were set up for the purpose of monitoring overall experimental conditions. To determine the reaction of $L$. littorea to ethanol, solvent control groups (named Ethanol in Figures 1 to 3 ) were injected with $4 \mu \mathrm{l} 10 \%$ ethanol. In each case, the specimens were analysed eight weeks after the start of the experiment.

(2) Four groups of laboratory experiments (a-d) were performed in glass aquaria filled with 80 litres of artificial seawater (instant ocean with a salinity of $35 \%$ ), and each were equipped with a 24 - to 48 -h static renewal system and an Eheim power filter. 
During the experiments, which lasted four or eight weeks (Table 1), the temperature was constant at $10^{\circ} \mathrm{C}$.

(a) Snails from the Helgoland sampling site were injected with 50 or $100 \mathrm{ng}$ TBT, either as Sn soluted in 2 or $4 \mu \mathrm{l} 10 \%$ ethanol or with the solvent only. These TBT solutions are identical to those used in the field experiments.

(b) Four groups of specimens collected at Sion d'Ocean (Baie d'Yves, Poitou, France) were kept in artificial seawater doped with 5, 50, 100 and $200 \mathrm{ng}$ TBT (Sn/l).

(c) One group of juvenile L. littorea (shell height $<11 \mathrm{~mm}$ ) sampled at Helgoland was kept in the artificial seawater containing $100 \mathrm{ng}$ TBT (Sn/l).

(d) Another group of specimens from Helgoland was kept in artificial seawater containing $33 \mathrm{ng} / \mathrm{l}$ testosterone.

The aqueous exposure experiments (b) to (d) were carried out for simulating uptake of toxicants from water. For these experiments the concentration of the contaminant in the seawater was adjusted after 48 hours. To assess affects of pre-experimental contamination, control groups were held for the duration of the tests in pure artificial seawater, but under otherwise unchanged conditions.

In each of the above given field and laboratory experiments, a subsample of 30 snails was analysed to determine the number of female specimens (compare Table 1). At the end of the experiments the snails were again narcotized in $7 \% \mathrm{MgCl}_{2}$, and their shells were cracked with a vice to facilitate the measurement of the external dimensions of the genital tract. Measured parameters in female individuals were the total length of gallert-, capsule-, and albumen-gland, and receptaculum seminis. For all parameters, the arithmetic mean and the standard variation were calculated. The statistical significance of the results was calculated by Student's t-test, and the error probability (p) was given for each case in Figures 1 to 6 (Weber, 1972).

\section{RESULTS}

\section{General aspects}

The most important outcome of the investigation is that indications of development of experimentally TBT-induced imposex are lacking in $L$. littorea, even in specimens suffering from very high contamination levels. All female individuals still display normal, unchanged genitals, and pathological growth of a penis has not been detected. Males used in these experiments, however, show drastic variations in the penis epithelium on the ultrastructural level, indicating that TBT has a significant impact on the genital tract of $L$. littorea (Deutsch et al., 1994). To verify this result, the gland complex in female individuals was studied in detail.

\section{Field experiments with TBT injection}

A linear relationship between reduction of the female gland complex of L. littorea and the injected TBT-dose was observed in the field experiments at Roscoff. In snails injected with 50 or $100 \mathrm{ng}$ TBT, the gland complex has, after eight weeks, a mean length of $16.5 \pm 3.8$ or $15.3 \pm 3.8 \mathrm{~mm}$ compared to $19.1 \pm 2.6 \mathrm{~mm}$ for the control group (Fig. 1). However, in relation to the mean length of $17.4 \pm 2.9 \mathrm{~mm}$ for the gland complex of the 


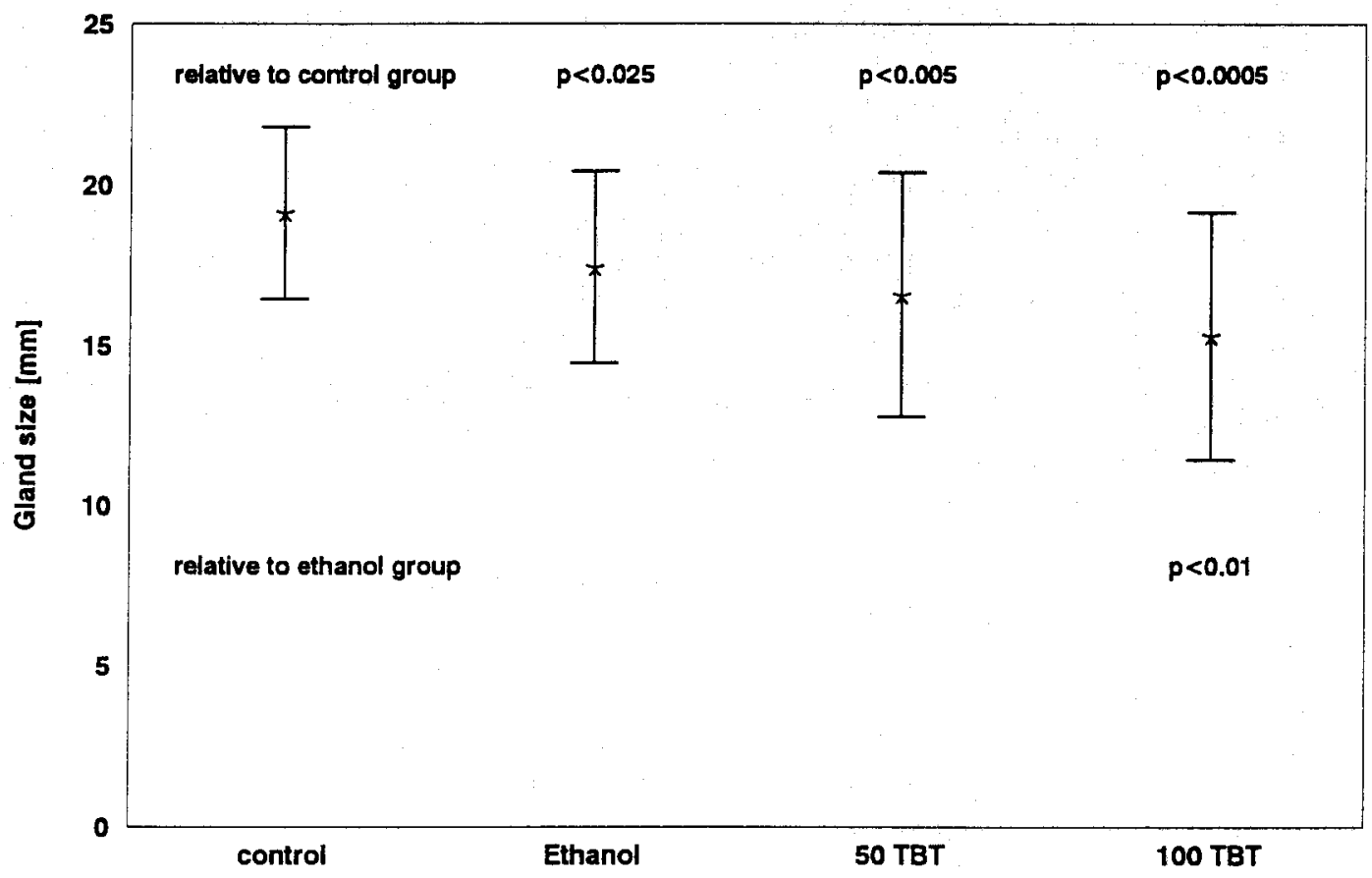

Fig. 1. Mean length in $\mathrm{mm}$ and standard deviation of the gland complex in female L. littorea injected with different amounts of TBT and ethanol (solvent group) for field experiment at Roscoff. The error probability $p$ from Student's t-test compared to the control (upper row) and solvent group (lower row). Compare Table 1 for $n$

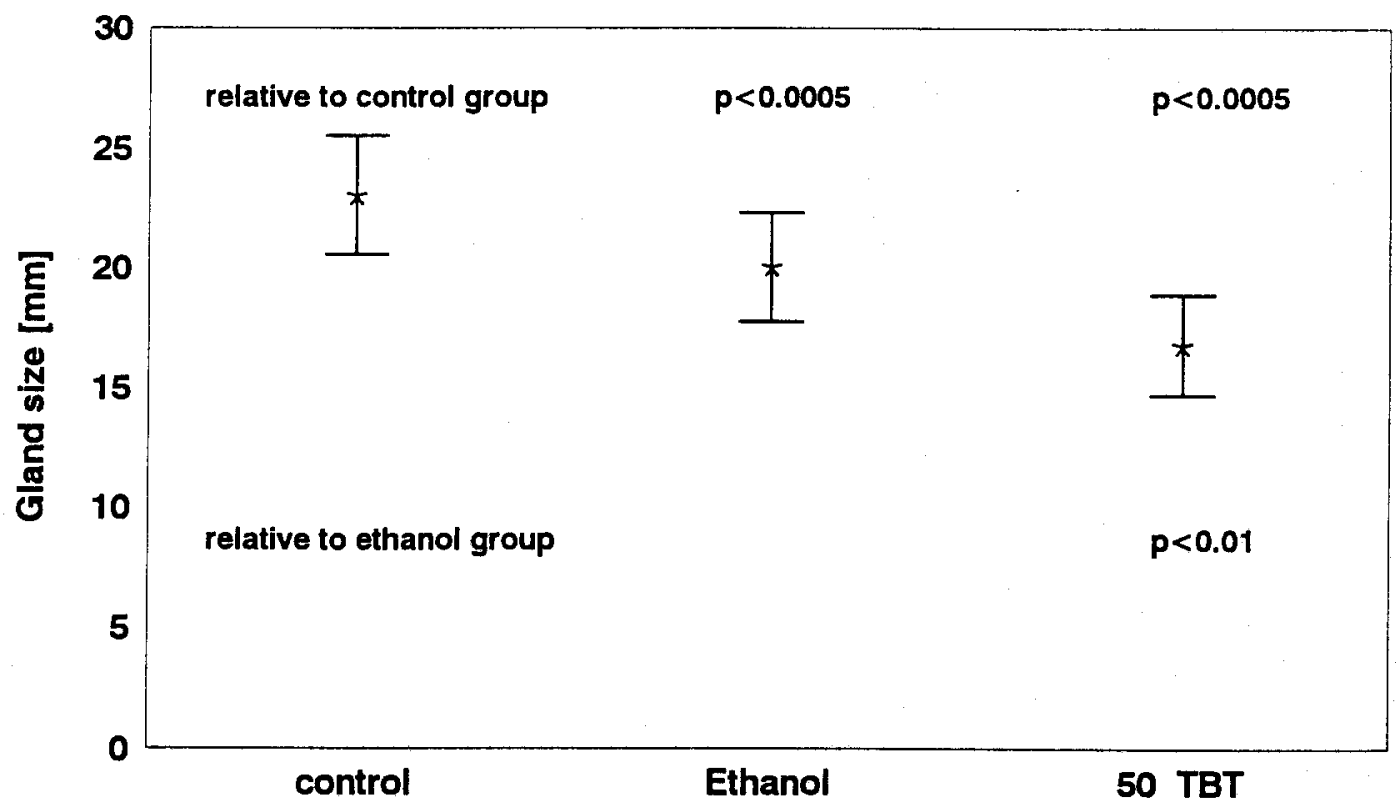

Fig. 2. Mean length in $\mathrm{mm}$ and standard deviation of the gland complex in female L. littorea injected with different amounts of TBT and ethanol (solvent group) for field experiment at Helgoland. The error probability $p$ from Student's t-test compared to the control (upper row) and solvent group (lower row). Compare Table 1 for $n$ 


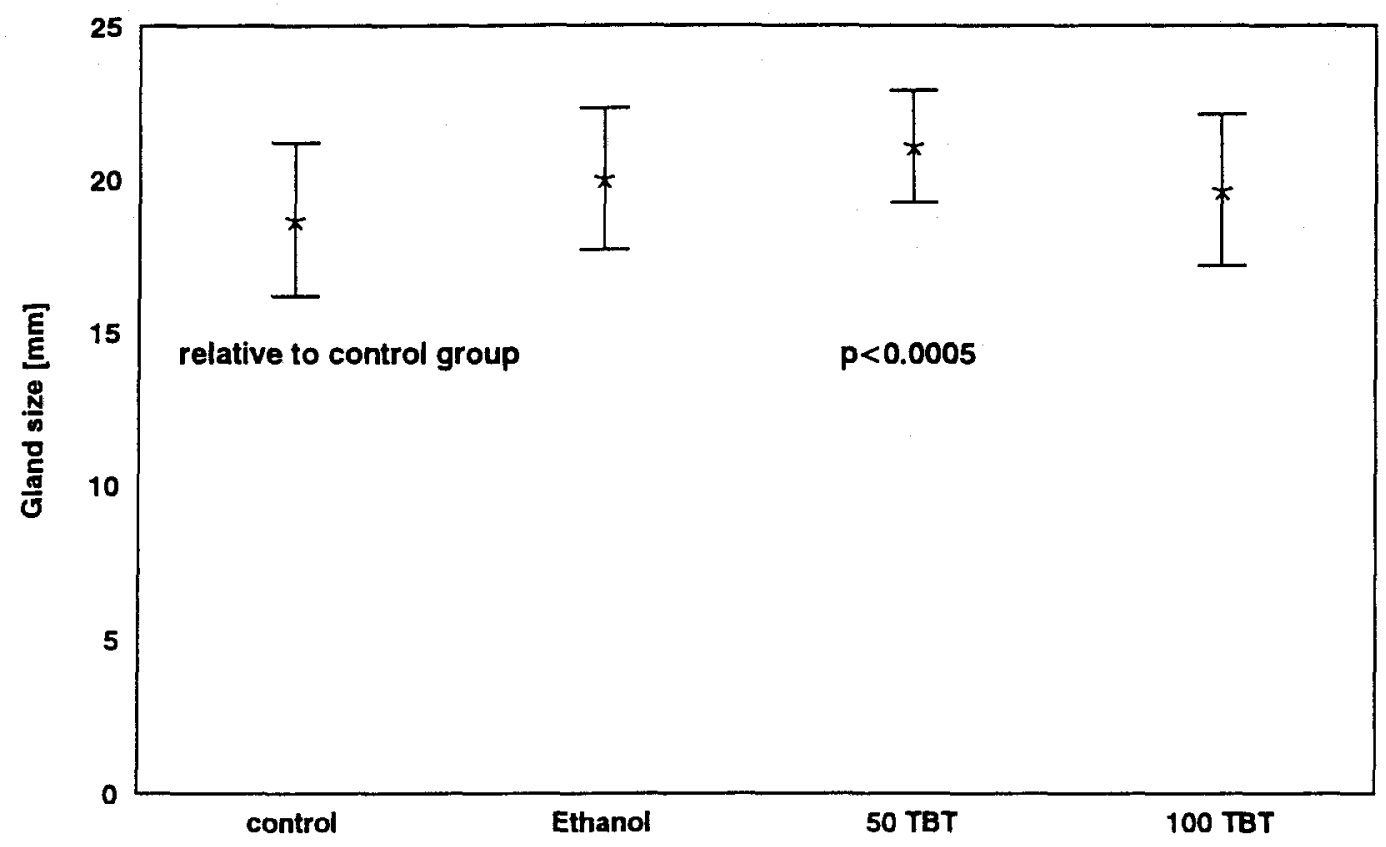

Fig. 3. Mean length in $\mathrm{mm}$ and standard deviation of the gland complex in female L. littorea injected with different amounts of TBT and ethanol (solvent group) for laboratory experiment with snails collected at Helgoland. The error probability $p$ from Student's t-test compared to the control (upper row) and solvent (Ethanol) group (lower row). See Table 1 for $n$

solvent group, the observed reduction is statistically only significant for specimens injected with $100 \mathrm{ng}$ TBT.

Data from the field experiments on Helgoland corroborate that TBT causes severe reduction of the $L$. littorea female gland complex. The mean length of the gland complex is $16.8 \pm 2.0 \mathrm{~mm}$ for specimens injected with $50 \mathrm{ng}$ TBT $(\mathrm{Sn} / \mathrm{l}), 23.0 \pm 2.5 \mathrm{~mm}$ for the control group, and $20.0 \pm 2.3 \mathrm{~mm}$ for the solvent group (Fig. 2). In contrast to the results from the Roscoff site, the difference between the injected solvent group and the injected TBT snails is also significant $(p<0.0005)$. Data for specimens injected with $100 \mathrm{ng}$ TBT are not available, because no snail survived treatment with the high dose.

\section{Laboratory experiments with TBT injection}

Laboratory experiments with injected snails from the Helgoland sampling site seemed to have inconclusive results. The group injected with $50 \mathrm{ng}$ TBT (Sn/1) yielded, in respect to the control group, an unexpected enhancement of the female gland complex, while snails injected with $100 \mathrm{ng} \mathrm{TBT}(\mathrm{Sn} / \mathrm{l})$ appeared to contain glands unchanged in size (Fig. 3). The mean length of this complex is $18.7 \pm 2.5 \mathrm{~mm}$ for the control group, $21.1 \pm 1.8 \mathrm{~mm}$ for specimens injected with $50 \mathrm{ng} \mathrm{TBT}, 19.6 \pm 2.5 \mathrm{~mm}$ for the $100 \mathrm{ng}$ TBT group, and $20.0 \pm 2.3 \mathrm{~mm}$ for the solvent group. The values observed for the groups 

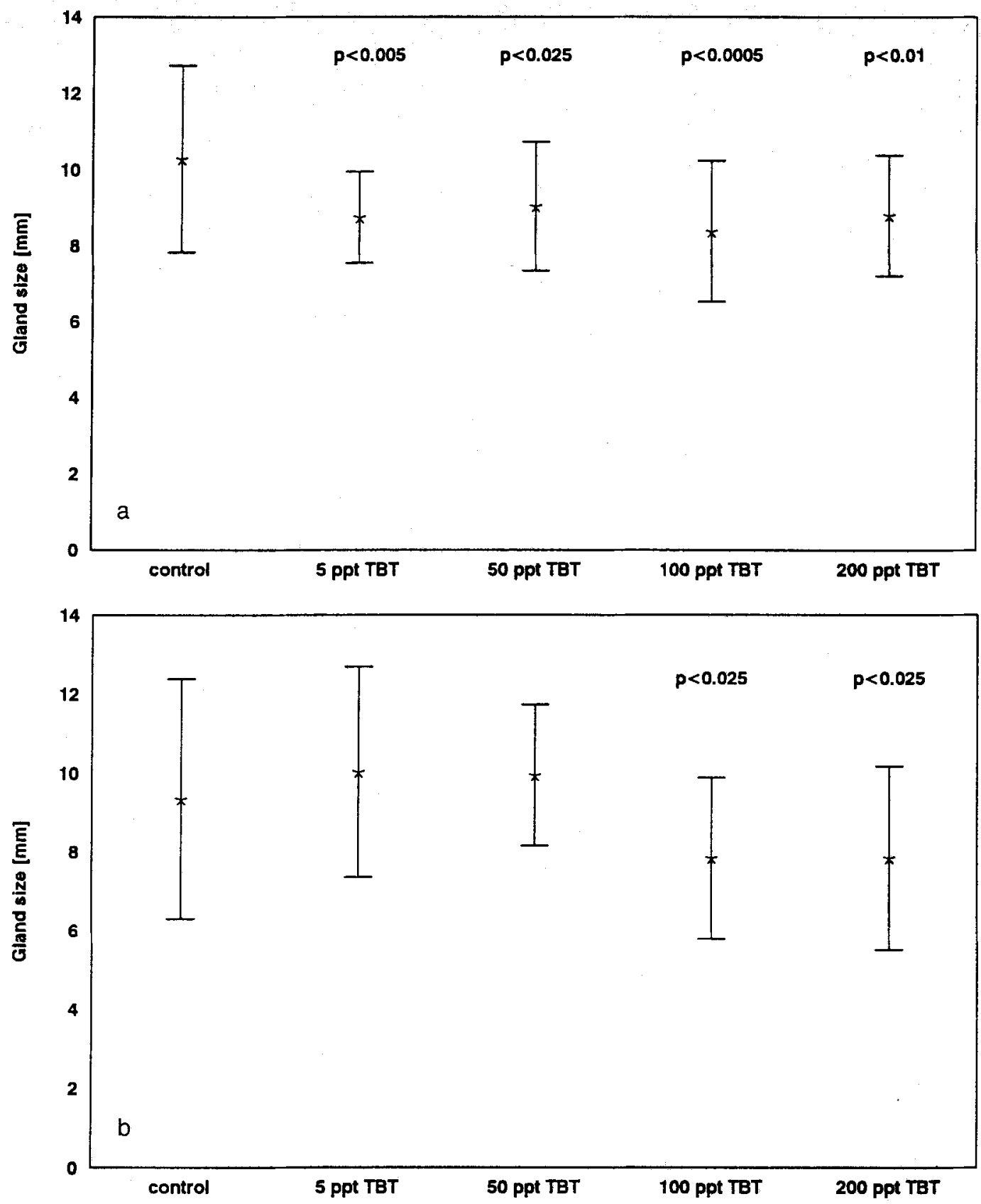

Figs $4 \mathrm{a}-\mathrm{b}$. Mean length in $\mathrm{mm}$ and standard deviation of the gland complex in female L. littorea exposed to different levels of TBT contamination in artificial seawater for four or eight weeks. The error probability $p$ from Student's t-test compared to the control group. The snails were sampled at Sion d'Ocean. Figure $4 \mathrm{a}$ illustrates the results after 4 weeks of the experiment; Figure $4 \mathrm{~b}: 8$ weeks after start of the experiment. See Table 1 for $n$ 
injected with 50 and $100 \mathrm{ng}$ TBT and the solvent are statistically indistinguishable (Fig. 3).

\section{Laboratory experiments with aqueous TBT uptake}

Aqueous exposure is a more realistic simulation of TBT contamination in nature than injection experiments. The drastic effects on the female gland complex induced by aqueous uptake of TBT are illustrated in Figure 4 for L. littorea sampled at Sion d'Ocean. A decrease in the mean length of the female gland complex was already obvious four weeks after the beginning of the experiments. Compared to a mean length of $10.3 \pm 2.5 \mathrm{~mm}$ of the gland complex in the control group, the mean length of the group kept in seawater with a TBT-Sn concentration of $5 \mathrm{ng} / \mathrm{l}$ was $8.7 \pm 1.2 \mathrm{~mm} ; 9.0 \pm 1.7 \mathrm{~mm}$ after exposure to water with $50 \mathrm{ng} / \mathrm{TBT}-\mathrm{Sn} ; 8.3 \pm 1.9 \mathrm{~mm}$ at a contamination level of $100 \mathrm{ng} / \mathrm{l} \mathrm{TBT}-\mathrm{Sn}$; and $8.8 \pm 1.6 \mathrm{~mm}$ at $200 \mathrm{ng} / \mathrm{l} \mathrm{TBT}-\mathrm{Sn}$ (Fig. $4 \mathrm{a}$ ). A linear relationship of gland complex reduction and TBT concentration in the artificial seawater was not observed. Further reduction of the female gland complex in L. littorea from Sion d'Ocean was observed after eight weeks exposure time. The mean length of the gland complex in the control group amounts to $9.3 \pm 3.0 \mathrm{~mm}$, but it is only $7.8 \pm 2.0$ and $7.8 \pm 2.3 \mathrm{~mm}$ for both the groups kept in aquaria with a TBT-Sn concentration of 100 or $200 \mathrm{ng} / \mathrm{l}$ (Fig. 4b).

Juvenile female (shell height $<11 \mathrm{~mm}$ ) L. littorea collected at the Helgoland site show a significant size reduction of the gland complex, but not before eight weeks

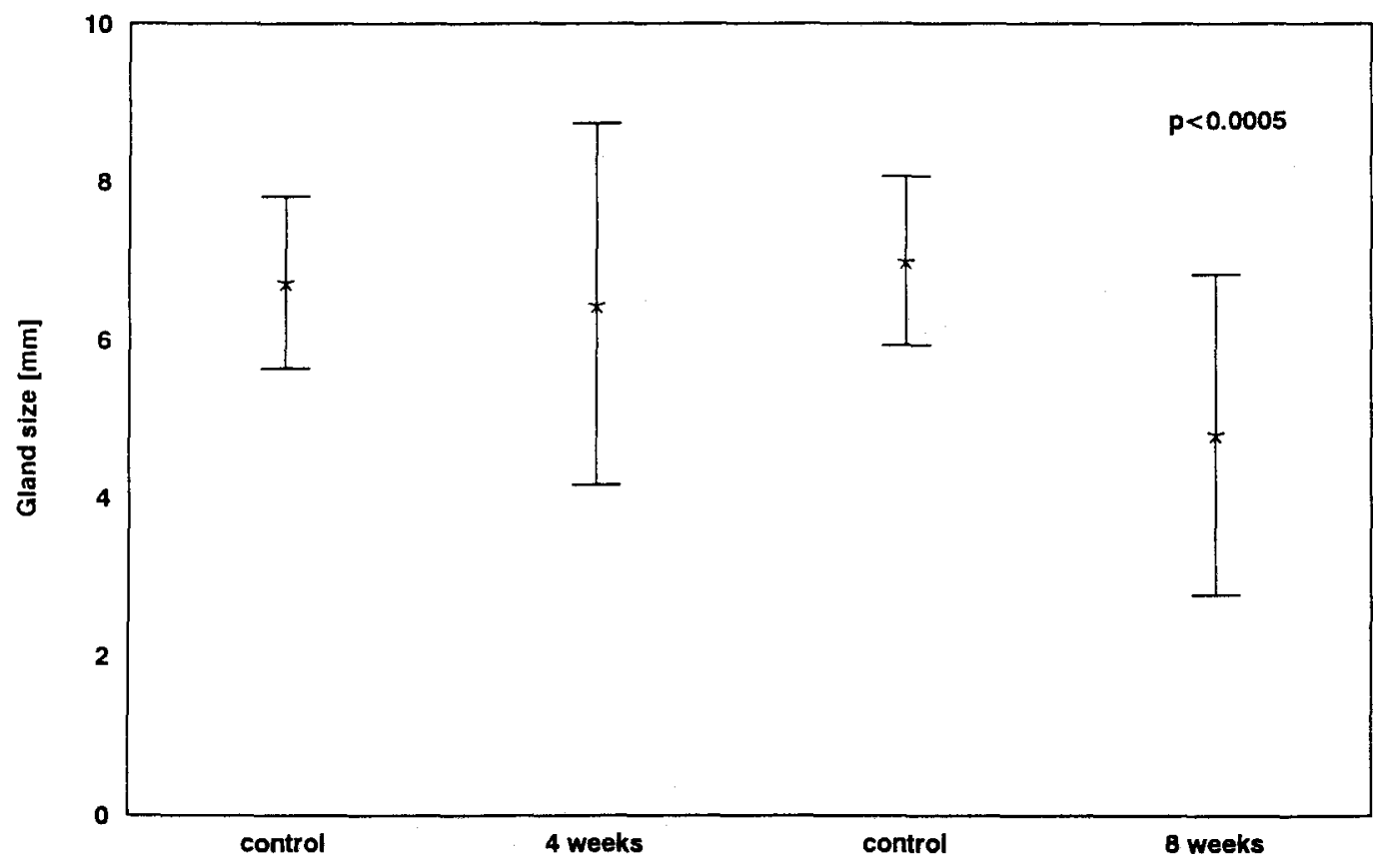

Fig. 5. Mean length in $\mathrm{mm}$ and standard deviation of the gland complex in juvenile female L. littorea exposed for four or eight weeks to artificial seawater containing $100 \mathrm{ng}$ TBT/l. The error probability $p$ from Student's t-test compared to the control group. The snails were sampled at Helgoland. See Table 1 for $n$ 


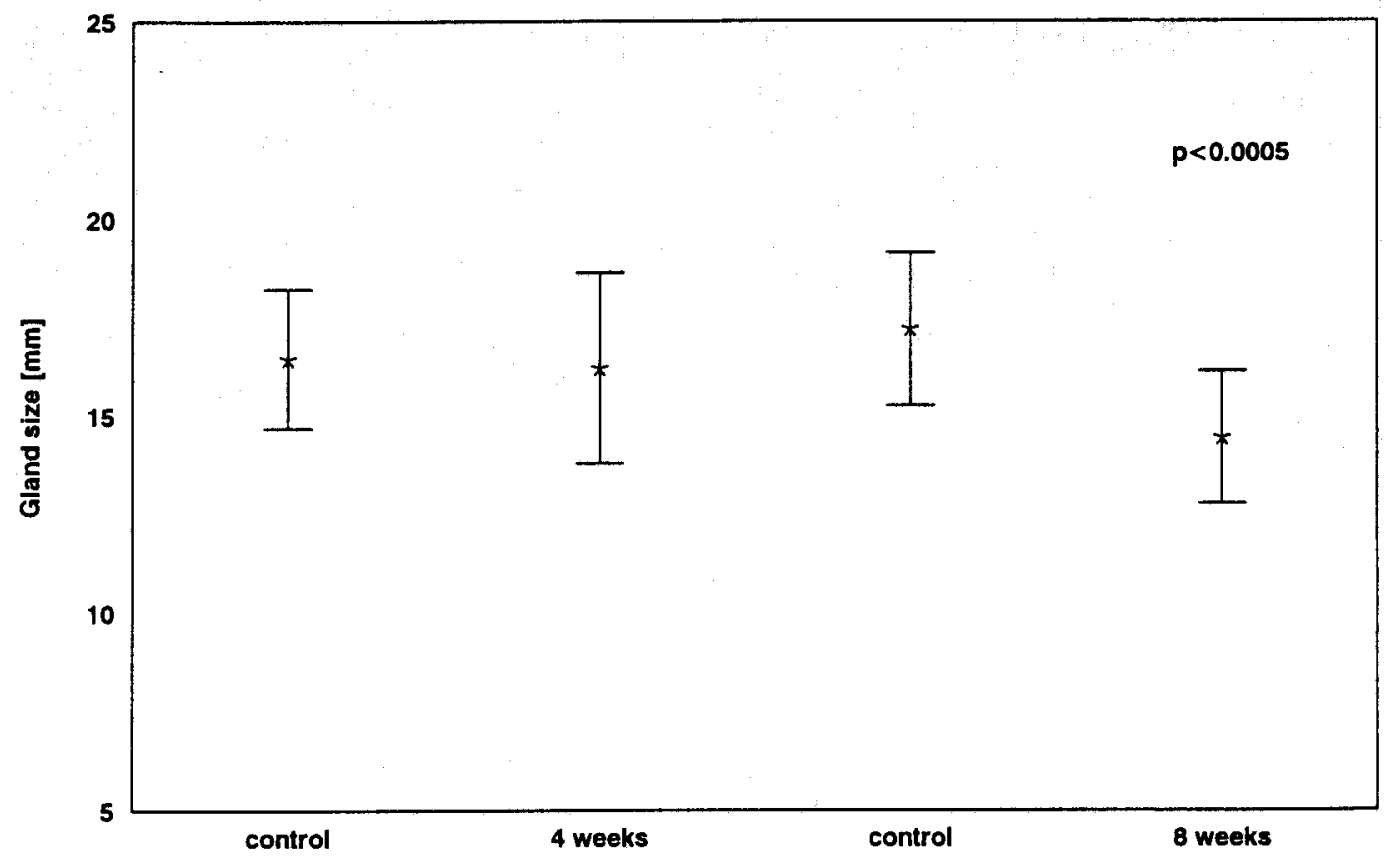

Fig. 6. Mean length in $\mathrm{mm}$ and standard deviation of the gland complex in female L. littorea exposed for eight weeks to artificial seawater containing $33 \mathrm{ng} / \mathrm{l}$ testosterone. The error probability $p$ from Student's t-test compared to the control group. The snails were sampled at Helgoland. See Table 1 for $n$

exposure time. As illustrated in Figure 5, the mean length of this complex is only $4.8 \pm 2.0 \mathrm{~mm}$ for the exposure group, compared to $7.0 \pm 1 \mathrm{~mm}$ for the control group. Both groups display an identical mean height of the shell, which may indicate reduced or even zero growth in the aquaria due to nutrition stress.

\section{Laboratory experiments with aqueous testosterone uptake}

Aqueous exposure of $L$. littorea to testosterone also results in significant decrease of the gland complex in female adults. After eight weeks exposure time in the doped seawater, the complex displays a mean length of $14.5 \pm 1.7 \mathrm{~mm}$, compared to $17.2 \pm 1.9 \mathrm{~mm}$ for the control group (Fig. 6). Again, indications for imposex development could not be found.

\section{DISCUSSION}

In keeping with earlier observations in the field (Matthiessen et al., 1991; Deutsch \& Brick, 1993; Deutsch et al., 1994), at least for the 8 weeks duration of the experiments, the female $L$. littorea did not develop signs of imposex in the laboratory experiments, despite high levels of aqueous TBT and testosterone exposure and high injected TBT doses. In other prosobranchs, however, this biocide causes hormonal disorders, which are responsible for imposex development (Stroben et al., 1991). The new results indicate that the lack 
of imposex in female L. littorea may be a corrollary of the missing androgen receptors at the ovipositor in this species.

Field experiments with TBT injection yielded significantly different results between Helgoland and Roscoff. The snails at Helgoland seem to react extremely sensitively to additional TBT because of already high pre-experimental TBT contamination from the seawater at the Helgoland biological station, which contains on average $8.78 \mathrm{ng} / \mathrm{l}$ TBT-Sn (Oehlmann et al., 1993b). The fact that all L. littorea injected with $100 \mathrm{ng}$ TBT (Sn/1) were killed at the Helgoland site is also ascribed to the extremely high "natural" TBT concentration in this region of the German Bight. In contrast, for seawater at the Roscoff CNRS station a TBT-Sn concentration of only $2.78 \mathrm{ng} / \mathrm{l}$ was determined (Oehlmann et al., 1993b), and hence, snails from this sampling site suffered only from a relatively moderate TBT background prior to injection experiments. It is attributed to the low TBT level at Roscoff that injection of $50 \mathrm{ng}$ TBT ( $\mathrm{Sn} / \mathrm{l}$ ) did not cause decrease in the gland complex size in comparison to the gland complex of the group injected only with ethanol.

Results of the laboratory injection experiments can also be explained by the origin of the snails in the highly contaminated Helgoland area. In the laboratory, these specimens decrease immediately from the high "natural" background TBT level. Despite the additionally injected TBT, the net result over the duration of the experiment might, therefore, be a lower time-integrated TBT contamination in the specimens causing, in consequence, growth of the gland complex.

Female individuals of the solvent groups, treated with ethanol only, display in all experiments a reduced gland complex; male L. littorea of the solvent groups are characterized by additional penis growth (Deutsch et al., 1994). These observations indicate that ethanol also causes hormonal disorders in the periwinkle. Such phenomena have already been described for other prosobranchs, e.g. Hinia reticulata and Nucella lapillus (Stroben et al., 1992b).

The significantly reduced gland complex of juvenile specimens, which were exposed to TBT-treated artificial seawater, indicate that the severe impact of TBT on the hormonal situation starts in the early stages of development. This reducing effect of TBT is most probably obscured by natural growth of the gland complex and, hence, becomes evident only after eight weeks of experimentation.

In the testosterone experiment with $L$. littorea, masculinization in the form of a reduced gland complex was observed. Similar high testosterone levels in the environment are known to induce imposex in female individuals of other prosobranchia (Stroben et al. 1991; Oehlmann et al., 1993a). It is presumed that the contamination level of $33 \mathrm{ng} / 1$ testosterone in the experiment with artificial seawater was below the threshold of imposex development in L. littorea. Perhaps testosterone does not act as the specific androgen in $L$. littorea. Further experiments using a different androgen, such as androstenedione for example, may help to solve this question.

An alternative explanation for the negative results is the relatively short duration of our experiments. Further experiments with $L$. littorea are planned in order to clarify if long-term exposure to TBT can induce morphological alteration. A recent study in a section of the Lower Saxonian North Sea coast, which is strongly polluted with TBT, has revealed alterations in the female genital system of $L$. littorea, but again, imposex phenomena were not observed (Watermann, pers. comm.).

The new experimental data show in accordance with earlier findings that the genital 
system of $L$. littorea responds to TBT-toxication differently, and with significantly lower sensitivity than that of other prosobranchs. However, it is known from other prosobranchs, like Trivia arctica and monacha (Stroben et al., 1992a), Ocenebra erinacea (Oehlmann et al., 1992b), and Hinia reticulata (Stroben et al., 1992c), that reduction of the gland complex occurs before the onset of morphological alterations. This fact should, in principal, allow determination of TBT-influence on archaeogastropods and on mesogastropod species without a penis. For biotopes, where only species without a penis occur, this may by of great interest in recognizing TBT-pollution.

In conclusion, TBT and probably other toxic organometallic compounds force reduction of the female gland complex in L. littorea, which is responsible for spawn-forming, and hence, reproductivity decreases. Consequently, continuous toxication of a population will end with masculinization of $L$. littorea. Such a reduction of the $L$. littorea population in periods with high TBT-concentration has already been described by Matthiessen et al. (1991) from the coast of southern England. Though L. littorea apparently lacks imposex, TBT is notwithstanding a very serious threat to L. littorea.

Acknowledgements. Support in field and laboratory work provided by the staff of the Biologische Anstalt Helgoland is gratefully acknowledged. We thank Prof. P. Lassere for permission to use laboratory facilities at the Observatoire Océanologique Roscoff. Thanks are also due to our colleagues Dr. J. Oehlmann and Dr. E. Stroben (Münster), and Dr. K. Janke (Helgoland) for help with the experiments at the Roscoff and the Helgoland stations. The review of an earlier draft of the paper by Dr. A. Deutsch (Münster) is appreciated. The results presented in this paper are part of U. Deutsch's Ph.D. thesis at the Westfälische-Wilhelms-Universität Münster.

\section{LITERATURE CITED}

Blaber, S. J. M., 1970. The occurrence of a penis-like outgrowth behind the right tentacle in spent females of Nucella lapillus (L.). - Proc. malacol. Soc. Lond. 39, 231-233.

Bryan, G. W., Gibbs, P. E., Hummerstone, L. G. \& Burt, G. R., 1986. The decline of the gastropod Nucella lapillus around south-west England: evidence for the effects of tributyltin from antifouling paints. - J. mar. biol. Ass. U.K. 66, 611-640.

Deutsch, U. \& Brick, M., 1992. The fine structure of the penis-epithelium of Littorina littorea (Gastropoda; Prosobranch) - No effects of tributyltin. In: Abstracts of the 11th International Malacological Congress, Siena 1992. Ed. by F. Giusti \& G. Manganelli. Univ. of Siena, Siena, $410-411$.

Deutsch, U. \& Brick, M., 1993. Morphological effects of tributyltin (TBT) in vitro on the genital system of Littorina littorea (Prosobranchia). - Helgoländer Meeresunters. 47, 49-60.

Deutsch, U., Oehlmann, J. \& Stroben, E., 1994. Morphological effects of tributyitin (TBT) on the genital system of the mesogastropod Littorina littorea (L.) (Prosobranchia) in vitro. - Malacol. Rev, 6, 143-148.

Fioroni, P., Oehlmann, J. \& Stroben, E., 1991. The pseudohermaphroditism of prosobranchs; morphological aspects. - Zool. Anz. 226, 1-26.

Matthiessen, P., Waldock, R., Thain, J. E., Milton, S. \& Scrope-Howe, S., 1991. Change in periwinkle (Littorina littorea) populations following the ban on TBT-based antifoulings on small boats. C. M./TCES E5, 1-15.

Oehlmann, J., Stroben, E. \& Fioroni, P., 1992. The rough tingle Ocenebra erinacea (Gastropoda: Muricidae): an exhibitor of imposex in comparison to Nucella lapillus. - Helgoländer Meeresunters. $46,311-328$

Oehlmann, J., Stroben, E., Bettin, C. \& Fioroni, P., 1993a. TBT-induzierter Imposex und seine physiologischen Ursachen bei marinen Vorderkiemenschnecken. In: SDN-Kolloquium Antifouling im Meer - Gefahren durch Schiffsanstriche. Emden 21. Januar 1993. Schutzgemeinschaft Deutsche Nordseeküste, Wilhelmshaven, 58-72. 
Oehlmann, J., Stroben, E. \& Fioroni, P., 1993b. Fréquence et degré d'expression du pseudohermaphrodisme chez quelques Prosobranches Sténoglosses des côtes françaises (surtout de la baie de Morlaix et de la Manche). 2. Situation jusqu'au printemps de 1992. - Cah. Biol, mar. 34, 343-362.

Smith, B. S., 1971. Sexuality in the american mud snail, Nassarius obsoletus Say. - Proc. malacol. Soc. Lond. 39, 377-378.

Stroben, E., Oehlmann, J. \& Bettin, C., 1991. TBT-induced imposex and the role of steroids in marine snails. In: Proceedings of the 10th World Meeting of ORTEP Association (Berlin 26./27. Sept. 1991). ORTEP Association, The Hague, 68-73.

Stroben, E., Brömmel, C., Oehlmann, J. \& Fioroni, P., 1992a. The genital system of Trivia arctica and Trivia monacha (Prosobranchia: Mesogastropoda) and tributyltin-induced imposex. - Zool. Beitr. $34,349-373$.

Stroben, E., Oehlmann, J. \& Fioroni, P., 1992b. The morphological expression of imposex in Hinia reticulata (Gastropoda: Buccinidae), a potential biological indicator of tributyltin pollution. Mar. Biol. 113, 625-636.

Stroben, E., Oehlmann, J. \& Fioroni, P., 1992c. Hinia reticulata and Nucella lapillus: a comparison of two gastropod tributyltin bioindicators. - Mar. Biol. 114, 289-296.

Weber, E. 1972. Grundriß der biologischen Statistik. Fischer, Stuttgart, 706 pp. 